\title{
PENGARUH GOOD CORPORATE GOVERNANCE, UKURAN PERUSAHAAN DAN INTELECTUAL CAPITAL TERHADAP MANAJEMEN LABA PADA PERUSAHAAN MANUFAKTUR YANG TERDAFTAR DI BEI
}

\author{
Sri Supatminingsih, Monot Wicaksono \\ STIE AAS Surakarta \\ Email : patminingsihsri@gmail.com
}

\begin{abstract}
Abstrak : Penelitian ini bertujuan untuk menguji pengaruh penerapan good corporate governance, ukuran perusahaan, dan modal intelektual terhadap praktek manajemen laba. Variabel dalam penelitian ini adalah Good Corporate Governance yang diproksikan ke dalam proporsi dewan komisaris dan keberadaan komite audit, variabel ukuran perusahaan dan modal intelektual. Sampel pada penelitian ini adalah 50 perusahaan manufaktur yang secara konsisten terdaftar di BEI pada rentang waktu 2015-2017. Metode penelitian yang digunakan dalam penelitian ini adalah menggunakan analisis regresi berganda, uji $F$, uji t, uji koefisien determinasi, serta uji asumsi klasik. Hasil penelitian menunjukkan bahwa good corporate governance, ukuran perusahaan, dan modal intelektual berpengaruh negatif tidak signifikan terhadap manajemen laba perusahaan-perusahaan manufaktur yang terdaftar di Bursa Efek Indonesia (BEI) periode 2015-2017.
\end{abstract}

Kata Kunci: Good Corporate Governance, ukuran perusahaan, modal intelektual, manajemen laba

\section{PENDAHULUAN}

Setiap perusahaan pada suatu periode akan melaporkan semua kegiatan keuangannya dalam bentuk ikhtisar keuangan atau laporan keuangan sebagai salah satu sumber informasi yang digunakan untuk menilai kinerja perusahaan. Laporan keuangan merupakan ringkasan dari transaksi-transaksi keuangan yang terjadi selama tahun buku yang bersangkutan. Chariri dan Ghozali (2007) menyatakan bahwa salah satu tujuan pelaporan keuangan adalah memberikan informasi keuangan yang dapat menunjukkan prestasi perusahaan dalam menghasilkan laba (earning per share). Informasi keuangan yang dapat menunjukkan prestasi perusahaan dalam menghasilkan laba adalah laporan laba rugi.

Laporan laba rugi digunakan oleh para investor untuk melihat profitabilitas perusahaan dan memprediksi prospek perusahaan di masa yang akan datang. Untuk tujuan menunjukkan prestasi perusahaan dalam menghasilkan laba, manajemen cenderung mengelola laba secara oprtunis dan melakukan manipulasi laporan keuangan agar menunjukkan laba yang memuaskan meskipun tidak sesuai dengan kondisi perusahaan yang sebenarnya. Manajemen perusahaan dapat menentukan kebijakan penggunaaan metode akuntansi dalam menyusun laporan keuangan untuk mencapai tujuan yang diinginkan perusahaan. Pilihan kebijakan akuntansi yang dilakukan manajer untuk tujuan spesifik disebut dengan manajemen laba. Menurut Evadewi dan Meiranto (2014) menjelaskan bahwa earnings management atau 
manajemen laba diduga muncul atau dilakukan oleh manajer atau para pembuat laporan keuangan dalam proses pelaporan keuangan suatu organisasi karena mereka mengharapkan suatu manfaat dari tindakan yang dilakukan.

Manajeman laba (earnings management) merupakan campur tangan manajemen dalam proses penyusunan laporan keuangan perusahaan bagi eksternal guna mencapai tingkat laba tertentu dengan tujuan untuk menguntungkan dirinya sendiri atau perusahaannya sendiri. Salah satu konsekuensi paling fatal akibat tindakan manajemen yang memanipulasi laba adalah perusahaan akan kehilangan dukungan dari para stakeholders-nya. Stakeholder akan memberikan respon negatif berupa tekanan dari investor, sanksi dari regulator, ditinggalkan rekan kerja, boikot dari para aktivis, dan pemberitaan negatif media massa. Tindakan tersebut wujud ketidakpuasan stakeholders terhadap kinerja perusahaan yang dimanipulasi, dan pada akhirnya berimbas merusak reputasi perusahaan di pasar modal.

Banyak kasus manipulasi keuangan yang muncul karena perusahaan melakukan earning management. Menurut Sutikno, dkk. (2014) pada tahun 2001 tercatat kasus keuangan pada perusahaan publik yang melibatkan manipulasi laporan keuangan oleh PT Lippo, Tbk. (Bank Lippo). Hal tersebut membuktikan bahwa praktik manipulasi laporan keuangan tetap dilakukan oleh pihak korporat meskipun sudah menjauhi periode krisis tahun 1997-1998. Selain kasus Bank Lippo, skandal Bank Century yang berawal pada tahun 2004 sampai dengan tahun 2013 ini belum tuntas permasalahan yang dialami karena lemahnya pengawasan oleh dewan komisaris, sehingga pemerintah Indonesia harus mengeluarkan dana talangan.

Manajemen laba yang dilakukan perusahaan muncul karena adanya hubungan agensi antara principal (pemegang saham) dan agent (manajer). Hubungan agensi antara pemegang saham dan manajer tersebut dijelaskan dalam teori keagenan. Masalah yang sering muncul dalam hubungan agensi antara pemegang saham dan manajer adalah terjadinya konflik agensi. Konflik agensi muncul ketika manajer mempunyai kewajiban untuk memaksimumkan kesejahteraan para pemegang saham, namun disisi lain manajer juga mempunyai kepentingan untuk memaksimumkan kesejahteraan mereka. Penyatuan kepentingan antara pihak manajer ini sering kali menimbulkan masalah keagenan atau agensi konflik. Pihak yang lebih mengetahui kondisi internal perusahaan dan prospek perusahaan dimasa yang akan datang adalah manajer yang bertindak sebagai agent, sedangkan pemegang saham mengetahui keadaan dan prospek perusahaan dimasa yang akan datang hanya melalui informasi yang diberikan oleh manajer. Oleh karena itu, manajer berkewajiban untuk memberikan informasi yang berkaitan dengan kondisi perusahaan kepada pemegang saham sebagai bentuk pemenuhan kewajiban dalam mengelola perusahaan. Informasi yang disampaikan terkadang diterima tidak sesuai dengan kondisi perusahaan sebenarnya. Kondisi ini dikenal sebagai informasi yang tidak simetris atau asimetri informasi (information asymmetric) (Ujiyantho dan Pramuka, 2007).

Terjadinya manipulasi laporan keuangan tersebut karena lemahnya penerapan corporate governance. Ciri utama dari lemahnya corporate governance adalah adanya tindakan mementingkan diri sendiri di pihak para manajer perusahaan. Menurut Forum for Corporate 
Governance in Indonesia FCGI (dalam Ningsaptiti, 2010) tujuan dari corporate governance adalah untuk menciptakan nilai tambah bagi semua pihak yang berkepentingan (stakeholders). Penerapan corporate governance secara konsisten yang berprinsip pada keadilan, transparansi, akuntanbilitas, dan pertanggungjawaban terbukti dapat meningkatkan kualitas laporan keuangan. Dengan adanya prinsip good corporate governance tersebut diharapkan dapat menjadi penghambat aktivitas rekayasa kinerja yang mengakibatkan laporan keuangan tidak mengambarkan nilai fundamental perusahaan (Jao dan Pagalung, 2011).

Faktor lain yang mempengaruhi praktik manajemen laba yaitu ukuran perusahaan. Terdapat dua pandangan tentang bentuk ukuran perusahan terhadap manajemen laba. Pandangan pertama, ukuran perusahaan yang kecil dianggap lebih banyak melakukan praktik manajemen laba daripada perusahaan besar. Hal ini dikarenakan perusahaan kecil cenderung ingin memperlihatkan kondisi perusahaan yang selalu berkinerja baik agar investor menanamkan modalnya pada perusahaan tersebut. Perusahaan yang besar lebih diperhatikan oleh masyarakat sehingga akan lebih berhati-hati dalam melakukan pelaporan keuangan sehingga berdampak perusahaan tersebut melaporkan kondisinya lebih akurat (Jao dan Pagalung, 2011). Akan tetapi, pandangan kedua memandang ukuran perusahan mempunyai pengaruh positif terhadap manajemen laba.

Menurut Llukani (2013) pada perusahaan besar mungkin kurang terlibat dalam manajemen laba. Perusahaan ukuran besar memiliki hubungan baik dengan auditor dan dapat bernegosiasi dengannya, membuat proses dan laporan audit menjadi lebih fleksibel. Selain itu, manajer dengan menjalankan kewenangannya dapat mempengaruhi struktur audit internal dan dapat dengan mudah mengatur hasilnya. Perusahaan besar juga dapat mengelola pendapatan untuk mengurangi risiko politik, sehingga perusahaan besar cenderung memperbesar keuntungan fiskal untuk meningkatkan dana eksternal.

Beberapa penelitian telah dilakukan mengenai pengaruh mekanisme corporate governance dan ukuran perusahaan terhadap manajemen laba. Penelitian yang dilakukan Hayati dan Gusnardi (2012) tentang pengaruh penerapan mekanisme good corporate governance terhadap manajemen laba menemukan bahwa kepemilikan manajerial dan komite audit tidak berpengaruh terhadap manajemen laba, kepemilikan institusional dan komisaris independen berpengaruh terhadap manajemen laba, dan secara simultan kepemilikan manajerial, kepemilikan institusional, komisaris independen dan komite audit berpengaruh terhadap manajemen laba.

Pada penelitian yang dilakukan Kristiani, dkk. (2014) tentang pengaruh mekanisme corporate governance dan ukuran perusahaan terhadap manajemen laba menemukan bahwa: kepemilikan institusional, kepemilikan manajerial, komposisi dewan komisaris, dan ukuran perusahaan tidak berpengaruh signifikan terhadap manajemen laba. Ukuran dewan komisaris berpengaruh signifikan positif terhadap manajemen laba. Komite audit berpengaruh tidak signifikan terhadap manajemen laba. Secara simultan kepemilikan institusional, kepemilikan manajerial, ukuran dewan komisaris, komposisi dewan komisaris, komite audit dan variabel ukuran perusahaan berpengaruh signifikan terhadap manajemen laba pada perusahaan 
manufaktur yang terdaftar di BEI periode 2013-2016.

Hasil penelitian yang dilakukan Izza (2016) menunjukkan bahwa variabel proporsi komisaris independen, kepemilikan manajerial, kepemilikan institusional terbukti tidak berpengaruh untuk mengurangi tindakan manajemen laba. Sedangkan ukuran perusahaan terbukti berpengaruh untuk mengurangi tindakan manajemen laba. Secara simultan variabel corporate governance (proporsi komisaris independen, kepemilikan manajerial, kepemilikan institusional) dan ukuran perusahaan terbukti berpengaruh untuk mengurangi tindakan manajemen laba. Pada penelitian yang dilakukan Uwuigbe, Peter, dan Oyeniyi (2014) mengungkapkan bahwa ukuran dewan direksi memiliki dampak negatif yang signifikan terhadap manajemen laba yang diproksikan dari nilai discretionary akrual. Di sisi lain, dualitas CEO memiliki dampak positif yang signifikan manajemen laba untuk perusahaan sampel di Nigeria. Sedangkan Patrick, Paulinus, dan Nympha (2015) dalam penelitiannya menemukan bahwa praktik tata kelola perusahaan atau corporate governance, seperti ukuran dewan direksi, ukuran perusahaan, independensi dewan, dan kekuatan komite audit memiliki pengaruh signifikan terhadap praktik manajemen laba pada perusahaan-perusahaan di Nigeria.

Mengacu pada beberapa penelitian terdahulu di atas, terdapat beberapa research gap antara penelitian yang satu dengan yang lainnya. Perbedaan- perbedaan tersebut terdapat pada tahun penelitian, beberapa variabel yang diteliti, objek penelitian, serta beberapa hasil atau temuan masing-masing penelitian. Penelitian ini dilakukan terhadap perusahaan manufaktur yang terdaftar di BEI periode 2014-2017. Berdasarkan paparan yang disampaikan maka tujuan penelitian ini adalah untuk mengetahui Pengaruh proporsi dewan komisaris, keberadaan komite audit, ukuran perusahaan dan modal intelektual Terhadap Manajemen Laba Pada Perusahaan Manufaktur yang Terdaftar di BEI.

\section{METODE}

\section{Jenis Penelitian dan Sumber Data}

Penelitian ini tergolong dalam penelitian kuantitatif. Dalam penelitian ini, data-data yang digunakan merupakan kumpulan angka dari proporsi dewan komisaris, komite audit, ukuran perusahaan, modal intelektual dan manajemen laba.

Penelitian ini menggunakan data sekunder yang berupa laporan keuangan perusahaan manufaktur yang terdaftar di BEI dalam kurun waktu 2015-2017. Sumber data diperoleh dari Indonesian Capital Market Directory (ICMD) dan situs resmi BEI.

\section{Populasi dan Sampel}

Populasi penelitian ini adalah perusahaan manufaktur yang terdaftar di Bursa Efek Indonesia (BEI) pada periode 2015-2017. Sedangkan, sampel penelitian yang akan digunakan dipilih dengan menggunakan metode purposive sampling. Metode purposive samplingini berdasarkan pada ciri-ciri atau sifat-sifat tertentu yang diperkirakan mempunyai sangkut paut erat dengan ciri-ciri atau sifat-sifat yang ada dalam populasi yang sudah diketahui sebelumnya (Narbuko dan Achmadi, 2004).

Kriteria-kriteria yang akan digunakan dalam pengambilan sampel adalah sebagai berikut : 
a) Perusahaan manufaktur yang konsisten terdaftar di BEI pada kurun waktu 2015-2017

b) Perusahaan yang mempublikasikan laporan keuangan tahunan untuk periode 31 Desember 2015-2017 yang dinyatakan dalam mata uang rupiah(Rp).

c) Pada laporan keuangan yang diterbitkan pada periode 31 Desember 2015-2017, mencantumkan informasi mengenai good corporate governance, data-data yang diperlukan untuk mengukur ukuran perusahaan, modal intelektual, serta data yang dapat dipergunakan untuk mendeteksi manajemen laba.

\section{Variabel Penelitian}

Variabel Penelitian pada Penelitian ini yaitu manajemen laba bertindak sebagai variabel dependen, sedangkan yang menjadi variabel independen adalah $G C G$, ukuran perusahaan, dan modal intelektual.

\section{Teknik Analisa Data}

1) regresi berganda

Analisis regresi berganda, analisis ini untuk mengetahui besarnya pengaruh variabel independen atau bebas terhadap variabel terikat. Maka persamaan dari model regresi berganda pada penelitian ini adalah sebagai berikut :

$$
\mathrm{ML}=\alpha+\beta_{1} \mathrm{GCG}_{\mathrm{PDK}}+\beta_{2} \mathrm{GCG}_{\mathrm{KA}}+\beta_{3} \mathrm{UP}+\beta_{4} \mathrm{MI}+\varepsilon
$$

Uji signifikansi statistik
a. Uji t
b. Uji F
c. Koefisien determinasi $\left(\mathrm{R}^{2}\right)$
d. Uji Asumsi klasik

\section{HASIL DAN PEMBAHASAN}

\section{Analisis Koefisien Regresi Linier Berganda}

Tabel 1. Hasil Analisis Regresi Linear

\begin{tabular}{lcrrrr}
\hline Model & B & Std. Error & Beta & $t$ & Sig. \\
\hline 1 (Constant) & 1,535 & 1,855 & & 0,828 & 0,412 \\
\hline $\begin{array}{l}\text { Prop. Dewan } \\
\text { Komisaris }\end{array}$ & $-0,0002$ & 0,004 & $-0,008$ & $-0,053$ & 0,958 \\
\hline Komite Audit & $-0,056$ & 0,017 & $-0,426$ & $-3,319$ & 0,002 \\
\hline Ukuran Perusahaan & $-0,006$ & 0,005 & $-0,145$ & $-1,144$ & 0,258 \\
\hline Modal Intelektual & $-0,056$ & 0,017 &,- 426 & $-3,319$ & 0,002 \\
\hline
\end{tabular}


Dari hasil uji regresi dapat diformulasikan persamaan regresi sebagai berikut: $\mathrm{Y}=1,535-0,0002\left(\mathrm{X}_{1}\right)-0,0,056\left(\mathrm{X}_{2}\right)-0,006\left(\mathrm{X}_{3}\right)-0,054\left(\mathrm{X}_{4}\right)$

Nilai konstanta sebesar 1,535; menunjukkan bahwa manajemen laba perusahaan manufaktur akan bernilai konstan sebesar 1,535, jika faktor-faktor proporsi komisaris independen, komite audit, ukuran perusahaan dan modal intelektual tetap atau tidak berubah nilainya.

\section{Analisis Uji Hipotesis}

a. Hasil Uji Koefisien Determinasi (R2)

Tabel 2. Hasil Uji Koefisien Determinasi

Model Summary

\begin{tabular}{llrrr}
\hline Model & $\mathrm{R}$ & $\mathrm{R}$ Square & \multicolumn{1}{c}{$\begin{array}{c}\text { Adjusted } \mathrm{R} \\
\text { Square }\end{array}$} & $\begin{array}{l}\text { Std. Error of } \\
\text { the Estimate }\end{array}$ \\
\hline 1 & 0,474 & 0,225 & 0,164 & 0,41636648
\end{tabular}

Dari Tabel 1, dapat diketahui bahwa besarnya Multiple Correlation Coefficient (R) adalah 0,474 yang berarti adanya hubungan yang cukup kuat dan bersifat positif antara Prop. Dewan Komisaris $\left(\mathrm{X}_{1}\right)$, Komite Audit $\left(\mathrm{X}_{2}\right)$, Ukuran Perusahaan $\left(\mathrm{X}_{3}\right)$, dan ukuran perusahaan $\left(\mathrm{X}_{4}\right)$ terhadap manajemen laba perusahaan manufaktur. Besarnya Multiple Coefficient of Determination (Adjusted $R$ Square) adalah 0,164 atau 16,4\% yang berarti $16,4 \%$ manajemen laba perusahaan manufaktur dapat dijelaskan oleh variabel kepemilikan institusional, kepemilikan manajerial, proporsi komisaris independen, dan kepemilikan institusional, sedangkan sisanya 83,6\% dijelaskan oleh variabel-variabel lain di luar model regresi yang dikembangkan dalam penelitian ini. Misalnya: profitabilitas, leverage, dan umur perusahaan.

\section{b. Analisis Uji Parsial (Uji t)}

Tabel 3. Hasil Uji t (Uji Parsial)

\begin{tabular}{|c|c|c|c|c|c|c|}
\hline & \multicolumn{5}{|c|}{$\begin{array}{c}\text { Coefficient } \\
s\end{array}$} \\
\hline & & $B$ & Std. Error & Beta & & \\
\hline 1 & (Constant) & 1,535 & 1,855 & & 0,828 & 0,412 \\
\hline & $\begin{array}{l}\text { Kepemilikan } \\
\text { Institusional }\end{array}$ & $-0,0002$ & 0,004 & $-0,008$ & $-0,053$ & 0,958 \\
\hline & $\begin{array}{l}\text { Kepemilikan } \\
\text { Manajerial }\end{array}$ & $-0,056$ & 0,017 & $-0,426$ & $-3,319$ & 0,002 \\
\hline
\end{tabular}




\begin{tabular}{llllll}
\hline $\begin{array}{l}\text { Prop. } \\
\text { Komisaris } \\
\text { Independen }\end{array}$ & $-0,006$ & 0,005 & $-0,145$ & $-1,144$ & 0,258 \\
\hline $\begin{array}{l}\text { Ukuran } \\
\text { Perusahaan }\end{array}$ & $-0,054$ & 0,061 & $-0,128$ & 0,881 & 0,383 \\
\hline
\end{tabular}

a. Dependent Variable: Manajemen laba

Berdasarkan analisis data yang telah dilakukan maka disampaikan hasil pengujian hipotesis sebagai berikut:

\section{1) Pengaruh Kepemilikan Institusional terhadap Manajemen Laba Perusahaan Manufaktur}

Hasil uji hipotesis menunjukkan bahwa kepemilikan institusional tidak berpengaruh signifikan terhadap manajemen laba perusahaan-perusahaan manufaktur yang terdaftar di Bursa Efek Indonesia (BEI) periode 2015-2017. Berdasarkan persamaan regresi yang diperoleh, diketahui bahwa terdapat hubungan yang negatif antara kepemilikan institusional dengan manajemen laba perusahaan-perusahaan manufaktur yang terdaftar di Bursa Efek Indonesia (BEI) periode 2015-2017. Dengan demikian, hasil penelitian ini menemukan bahwa kepemilikan institusional berpengaruh negatif tidak signifikan terhadap manajemen laba perusahaanperusahaan manufaktur yang terdaftar di Bursa Efek Indonesia (BEI) periode 2014-2017. Hasil penelitian ini mendukung temuan penelitian yang dilakukan Kristiani, dkk. (2014) dan Kumala (2016) yang menemukan bahwa kepemilikan institusional tidak berpengaruh signifikan terhadap manajemen laba.

Kepemilikan institusional merupakan kepemilikan saham yang dimiliki oleh investor institusi. Pemilik institusional merupakan pemilik yang dianggap cenderug lebih hatihati dan teliti dalam menggunakan informasi keuangan. Selain itu, tindakan pengawasan yang dilakukan oleh sebuah perusahaan dan investor institusional dapat membatasi perilaku manajer. Dengan demikian, keberadaan investor institusional dapat mendorong manajer untuk mendorong perhatiaannnya terhadap kinerja perusahaan sehingga investor institusional dianggap mampu menjadi mekanisme monitoring yang efektif dalam setiap keputusan yang diambil oleh manajer. Berdasarkan penjelasan di atas, dapat disimpulkan bahwa semakin besar saham yang dimiliki oleh pemegang saham institusional akan meminimalisir tindakan manajer untuk melakukan manajemen laba melalui manipulasi aktivitas riil.

\section{2) Pengaruh Kepemilikan Manajerial terhadap Manajemen Laba Perusahaan Manufaktur}

Hasil uji hipotesis menunjukkan bahwa kepemilikan manajerial berpengaruh signifikan terhadap manajemen laba perusahaan-perusahaan manufaktur yang terdaftar di Bursa Efek Indonesia (BEI) periode 2015-2017. Berdasarkan persamaan regresi yang diperoleh, diketahui bahwa kepemilikan manajerial memiliki hubungan yang negatif dengan manajemen laba perusahaan-perusahaan manufaktur yang terdaftar di Bursa Efek Indonesia (BEI) periode 20152017. Dengan demikian, hasil penelitian ini menemukan bahwa kepemilikan manajerial berpengaruh negatif dan signifikan terhadap manajemen laba perusahaan-perusahaan manufaktur 
yang terdaftar di Bursa Efek Indonesia (BEI) periode 2014-2017. Hasil penelitian ini mendukung temuan penelitian yang dilakukan Ujiyantho dan Pramuka (2007) yang menyatakan adanya pengaruh negatif antara kepemilikan manajerial dengan manajemen laba.

Kepemilikan manajerial merupakan kepemilikan saham yang dimiliki oleh manajemen perusahaan. Ada tidaknya kepemilikan saham oleh manajemen akan mepengaruhi motivasi manajemen dalam setiap tindakan manajer. Kepemilikan saham oleh manajemen dapat menyetarakan kepentingan pemegang saham dengan manajer sehingga konflik kepentingan dapat dikurangi. Selain itu, semakin besar proporsi kepemilikan manajemen pada perusahaan maka manajemen cenderung berusaha lebih giat untuk memaksimalkan kepentingan pemegang saham yang juga termasuk dirinya sendiri. Jadi, dapat disimpulkan bahwa semakin besar saham yang dimiliki oleh manajemen dapat mengurangi motivasi manajer untuk melakukan manajemen laba melalui manipulasi aktivitas riil.

\section{3) Pengaruh Proporsi Komisaris Independen terhadap Manajemen Laba Perusahaan Manufaktur}

Hasil uji hipotesis menunjukkan bahwa proporsi komisaris independen tidak berpengaruh signifikan terhadap manajemen laba perusahaan- perusahaan manufaktur yang terdaftar di Bursa Efek Indonesia (BEI) periode 2015-2017. Berdasarkan persamaan regresi yang diperoleh, diketahui bahwa terdapat hubungan yang negatif antara proporsi komisaris independen dengan manajemen laba perusahaan- perusahaan manufaktur yang terdaftar di Bursa Efek Indonesia (BEI) periode 2015-2017. Dengan demikian, hasil penelitian ini menemukan bahwa proporsi komisaris independen berpengaruh negatif tidak signifikan terhadap manajemen laba perusahaan-perusahaan manufaktur yang terdaftar di Bursa Efek Indonesia (BEI) periode 2015-2017. Hasil penelitian ini mendukung temuan penelitian yang dilakukan Kumala (2016) yang menemukan bahwa proporsi komisaris independen tidak berpengaruh signifikan terhadap manajemen

laba.

Proporsi komisaris independen adalah perbandingan jumlah komisaris independen yang dimiliki suatu perusahaan terhadap jumlah seluruh anggota dewan komisaris. Semakin tinggi proporsi komisaris independen maka semakin baik fungsi pengawasan terhadap manajemen, sehingga dapat menghambat praktik manajemen laba. Tidak berpengaruhnya proporsi komisaris independen dapat terjadi karena pengangkatan dewan komisaris oleh perusahaan mungkin hanya dilakukan untuk pemenuhan regulasi saja tapi tidak dimaksudkan untuk menegakkan Good Corporate Governance (GCG) di dalam perusahaan. Ketentuan minimum dewan komisaris independen sebesar 30\% mungkin belum cukup tinggi untuk menyebabkan para komisaris independen tersebut dapat mendominasi kebijakan yang diambil oleh dewan komisaris. Jika komisaris independen merupakan pihak mayoritas (> 50\%) mungkin dapat lebih efektif dalam menjalankan peran monitoring dalam perusahaan. 


\section{4) Pengaruh Ukuran Perusahaan terhadap Manajemen Laba Perusahaan Manufaktur}

Hasil uji hipotesis menunjukkan bahwa ukuran perusahaan tidak berpengaruh signifikan terhadap manajemen laba perusahaan-perusahaan manufaktur yang terdaftar di Bursa Efek Indonesia (BEI) periode 2015-2017. Berdasarkan persamaan regresi yang diperoleh, diketahui bahwa terdapat hubungan yang negatif antara ukuran perusahaan dengan manajemen laba perusahaan-perusahaan manufaktur yang terdaftar di Bursa Efek Indonesia (BEI) periode 20152017. Dengan demikian, hasil penelitian ini menemukan bahwa ukuran perusahaan berpengaruh negatif tidak signifikan terhadap manajemen laba perusahaan-perusahaan manufaktur yang terdaftar di Bursa Efek Indonesia (BEI) periode 2015-2017.

Hasil penelitian ini mendukung temuan penelitian yang dilakukan Pada penelitian yang dilakukan Dewi, dkk. (2017) diketahui bahwa ukuran perusahaan tidak berpengaruh terhadap manajemen laba pada perusahaan properti yang terdaftar di Bursa Efek Indonesia. Pada penelitian dengan judul yang berbeda, Astuti, dkk. (2017) juga membuktikan bahwa ukuran perusahaan tidak berpengaruh signifikan terhadap manajemen laba perusahaan-perusahaan perbankan yang terdaftar di Bursa Efek Indonesia (BEI) periode 2015-2017.

Berdasarkan annual report pada perusahaan-perusahaan yang menjadi objek penelitian ini, dapat diidentifikasikan bahwa pada perusahaan yang memiliki total asset sedang dan besar tidak terbukti lebih agresif dalam melakukan manajemen laba melalui pelaporan laba positif, baik untuk menghindari earning losses maupun earning decreases. Semakin besar perusahaan akan cenderung untuk tidak menunjukkan praktik manajemen laba karena perusahaan besar secara politis lebih mendapat perhatian dari institusi pemerintahan dibandingkan dengan perusahaan kecil. Semakin besar asset yang dimiliki perusahaan, maka semakin banyak modal yang ditanam dan semakin banyak penjualan sehingga besar perputaran uang yang terjadi, dan semakin besar kapitalisasi pasar. Kondisi tersebut akan membuat perusahaan semakin banyak dikenal masyarakat sehingga untuk perusahaan besar seharusnya dapat memenuhi ekspektasi yang diharapkan oleh investor. Oleh karena itu, dapat digarisbawahi bahwa perusahaan yang lebih besar, dalam arti mengukur perusahaan bukan hanya dengan melihat berapa jumlah dari total assets yang dimiliki perusahaan. Hal ini dimungkinkan karena ukuran besarnya suatu perusahaan tidak selamanya dapat diukur dengan total aktiva, sehingga memungkinkan adanya komponen lain yang dapat dijadikan sebagai parameter ukuran perusahaan, misalnya harga saham.

Ukuran perusahaan tidak berpengaruh terhadap manajemen laba. Hal ini menunjukkan bahwa ukuran perusahaan belum tentu dapat memperkecil kemungkinan terjadinya manajemen laba, karena perusahaan besar lebih banyak memiliki aset dan memungkinkan banyak aset yang tidak dikelola dengan baik sehingga kemungkinan kesalahan dalam mengungkapan total aset dalam perusahaan tersebut. Pengawasan yang ketat dari pemerintah, analis, dan investor yang ikut menjalankan perusahaan menyebabkan manajer tidak berani melakukan praktik perataan laba (income smoothing) yang merupakan salah satu teknik dalam manajemen laba. Hal ini dikarenakan dengan pengawasan yang ketat tersebut jika manajer melakukan praktik perataan laba, besar kemungkinan akan diketahui oleh pemerintah, analis, dan investor sehingga hal ini dapat merusak citra dan kredibilitas manajer perusahaan tersebut. 


\section{KESIMPULAN}

Berdasarkan hasil penelitian tentang pengaruh mekanisme corporate governance, yang meliputi kepemilikan institusional, kepemilikan manajerial, serta proporsi komisaris independen dan ukuran perusahaan terhadap manajemen laba perusahaan-perusahaan manufaktur sektor yang terdaftar di Bursa Efek Indonesia periode 2015-2017, dapat diambil beberapa simpulan sebagai berikut:

1) Kepemilikan institusional berpengaruh negatif tidak signifikan terhadap manajemen laba perusahaan-perusahaan manufaktur yang terdaftar di Bursa Efek Indonesia (BEI) periode 2015-2017. Semakin besar saham yang dimiliki oleh pemegang saham institusional akan meminimalisir tindakan manajer untuk melakukan manajemen laba melalui manipulasi aktivitas riil.

2) Kepemilikan manajerial berpengaruh negatif dan signifikan terhadap manajemen laba perusahaan-perusahaan manufaktur yang terdaftar di Bursa Efek Indonesia (BEI) periode 2015-2017. Semakin besar proporsi kepemilikan manajemen pada perusahaan maka manajemen cenderung berusaha lebih giat untuk memaksimalkan kepentingan pemegang saham yang juga termasuk dirinya sendiri. Semakin besar saham yang dimiliki oleh manajemen dapat mengurangi motivasi manajer untuk melakukan manajemen laba melalui manipulasi aktivitas riil.

3) Proporsi komisaris independen berpengaruh negatif tidak signifikan terhadap manajemen laba perusahaan-perusahaan manufaktur yang terdaftar di Bursa Efek Indonesia (BEI) periode 2015-2017. Tidak berpengaruhnya proporsi komisaris independen dapat terjadi karena pengangkatan dewan komisaris oleh perusahaan hanya dilakukan untuk pemenuhan regulasi saja, tetapi tidak dimaksudkan untuk menegakkan Good Corporate Governance (GCG) di dalam perusahaan.

4) Ukuran perusahaan berpengaruh negatif tidak signifikan terhadap manajemen laba perusahaan-perusahaan manufaktur yang terdaftar di Bursa Efek Indonesia (BEI) periode 2015-2017. Ukuran besarnya suatu perusahaan tidak selamanya dapat diukur dengan total aktiva, sehingga memungkinkan adanya komponen lain yang dapat dijadikan sebagai parameter ukuran perusahaan, misalnya harga saham.

5) Kepemilikan institusional, kepemilikan manajerial, proporsi komisaris independen, dan ukuran perusahaan secara simultan berpengaruh terhadap manajemen laba pada perusahaan manufaktur yang terdaftar di BEI periode 2015-2017. Penerapan mekanisme good corporate governance yang diproksikan dari kepemilikan institusional, kepemilikan manajerial, proporsi komisaris independen diharapkan dapat menjadi penghambat aktivitas rekayasa kinerja melalui praktik manajemen laba. Ditinjau dari ukuran perusahaan, maka perusahaan kecil dianggap lebih banyak melakukan praktik manajemen laba karena cenderung ingin memperlihatkan kondisi perusahaan yang selalu berkinerja baik agar investor menanamkan modalnya pada perusahaan tersebut. Sebaliknya, pada perusahaan besar lebih diperhatikan oleh masyarakat sehingga akan lebih berhati-hati dalam melakukan pelaporan keuangan sehingga berdampak perusahaan tersebut melaporkan kondisinya lebih akurat tanpa melakukan praktik manajemen laba. 


\section{DAFTAR PUSTAKA}

Abdulsalam, Fayez., Hameed Al-Qaheri., Ridha Al-Khayyat. 2011 The Intellectual Capital Performance of Kuwaiti Banks: An Application of VAIC ${ }^{\mathrm{TM}}$ Model. iBusiness. Hal.88-96.

Cornett, Marcia Millon., Alan J. Marcus., Hassan Tehranian. 2008. Corporate Governance and Pay-for-Performance : The Impact of Earning Management. Journal of Financial Economics 87. Hal. 357-373.

Dechow, Patricia M., Sloan M., Jung HK., Richard G. 2011. Detecting Earning Management: A New Approach.

Dechow, Patricia M., Sloan M., Sweeny AP. 1995. Detecting Earning Management. The Accounting Review Vol. 70.

Eisenhardt, Kathleem. M. 1989. Agency Theory: An Assesment and Review. Academy of Management Review, 14. Hal 57-74.

Handayani, RR. Sri., dan Agustono Dwi Rachadi. 2009. Pengaruh Ukuran Perusahaan terhadap Manajemen Laba. Jurnal Bisnis dan Akuntansi. Vol.1. No.1.

Irsyad, Muhammad. 2011. Pengaruh Good Corporate Governance terhadap Manajemen Laba pada Perusahaan Manufaktur yang Terdaftar di Bursa Efek Indonesia. Departemen Akuntansi Fakultas Ekonomi. Universitas Sumatera Utara.

Islam, MZ., Mohammad N.I., A.K.M. Zahirul Islam. 2010. Agency Problem and the Role of Audit Committee: Implications for Corporate Sector in Bangladesh. International Journal of Economics and Finance Vol.2.

Jao, Robert., dan Gagaring Pagalung. 2011. Corporate Governance, Ukuran Perusahaan, dan Leverage terhadap Manajemen Laba Perusahaan Manufaktur Indonesia. Jurnal Akuntansi \& Auditing. Vol. 8.

Jensen, Michael C., dan W.H. Meckling. 1976. Theory of The Firm: Managerial Behavior, Agency Cost and Ownership Structure. Journal of Financial Economics 3. Hal. 305-360.

Komite Nasional Kebijakan Governance. 2006. Pedoman Umum Good Corporate Governance Indonesia.

Marai, Awidat., dan Vladan Pavlović. 2013. Earnings Management Vs Financial Reporting Fraud - Key Features for Distinguishing. Facta Universitatis, Series: Economics and Organization. Vol.10.

Nassirzadeh, Farzaneh., Mahdi Salehi., Sayed M.A. 2012 A Study of the Factors Affecting Earnings Management: Iranian Overview. Science Series Data Report. Vol.4. No.2.

Naz, Iram., Khurram B., Abdul G., Habib H.K. 2011. Impact of Firm Size and Capital Structure on Earning Management. International Journal of Contemporary Business Studies. Vol. 2, No: 12.

Nikoomaram, Hashem., Bahman B., Azam S. 2012. An Empirical Analysis of Earnings Management Motives in Firms Listed on Tehran Stock Exchange. Journal of Basic and Applied Scientific Research. 
Sefiana, Eka. 2009. Pengaruh Penerapan Corporate Governance terhadap Manajemen Laba pada Perusahaan Perbankan yang Telah Go Public di BEI. Jurusan Akuntansi Fakultas Ekonomi, Universitas Gunadarma. Jakarta.

Setyawati, Nanik. 2010. Analisis Kesalahan Berbahasa Indonesia Teori dan Praktek. Surakarta.

Shelifer, Andrei., dan Robert W. Vishny. 1997. A Survey of Corporate Governance. The Journal of Finance. Vol.52. No.2.

Siregar, Silvia Veronica N.P., dan Sidharta Utama. 2005. Pengaruh Struktur Kepemilikan, Ukuran Perusahaan, dan Praktek Corporate Governance trhadap Pengelolaan Laba (Earnings Management). Simposium Nasional Akuntansi VIII. Solo.

Surat Keputusan Ketua BAPEPAM No.KEP-29/BL/2004. 2004. Peraturan No. IX.I.5: Pembentukan dan pedoman Pelaksanaan Kerja Komite Audit. Jakarta.

Suwasono, H. (2019). Pengaruh Financial Distress, Corporate Governance dan Karakteristik Perusahaan Terhadap Pengungkapan Sukarela pada Laporan Tahunan Perusahaan (Studi Empiris pada Perusahaan Manufaktur yang Terdaftar di Bursa Efek Indonesia Periode 2012-2016). Media Akuntansi, 31(02), 26-26.

The Indonesian Institute For Corporate Governance. 2012. Program Tahunan Riset dan Pemeringkatan Penerapan Good Corporate Governance: Corporate Governance Index. Jakarta.

Ujiyantho, Muh. Arief., dan Bambang Agus Pramuka. 2007. Mekanisme Corporate Governance, Manajemen Laba dan Kinerja Keuangan (Studi pada Perusahaan Go Publik Sektor Manufaktur). Simposium Nasional Akuntansi X. Makassar.

Utami, Rini Budi, dan Rahmawati. 2008. Pengaruh Komposisi Dewan Komsisaris dan Keberadaan Komite Audit terhadap Aktivitas Manajemen Laba pada Perusahaan Manufaktur yang Terdaftar di Bursa Efek Jakarta. Prosiding Seminar Ketahanan Ekonomi Nasional, UPN Veteran Yogyakarta. Yogyakarta.

Wahyono, R. Erdianto Setyo., Wahidahwati., Agus Sunaryo. 2013. Pengaruh Corporate Governance pada Praktik Manajemen Laba: Studi Pada Industri Perbankan Indonesia. Jurnal Ilmu dan Riset Akuntansi.Vol 1. No.2.

Waweru, Nelson M., dan George K. Riro. 2013. Corporate Governance, Firm Characteristics and Earnings Management in an Emerging Economy. JAMAR. Vol. 11. No.1.

Widyaningrum, Ambar. 2004. Modal Intelektual. Jurnal Akuntansi dan Keuangan, Depertemen Akuntansi FEUI. Jakarta.

Wulandari, Ratna Ayu. 2010. Pengaruh Sistem Hukum terhadap Manajemen Laba dengan Kepemilikan Institusional sebagai Variabel Pemoderasi: Studi Perbandingan Inggris dan Perancis. Simposium Nasional Akuntansi XIII. Purwokerto.

Yuniasih, Ni Wayan., Dewa G.W., I Dewa N.B. 2010. Eksplorasi Kinerja Pasar Perusahaan: Kajian Berdasarkan Modal Intelektual (Studi Empiris pada Perusahaan Keuangan yang Terdaftar di Bursa Efek Indonesia). Simposium Nasional Akuntansi XIII. Purwokerto.

Yushita, Amanita Novi. 2010. Earnings Management dalam Hubungan Keagenan. Jurnal Pendidikan Akuntansi Indonesia Vol. VIII. No. 1 - Tahun 2010. Jakarta 